\title{
Effects of hot-washing process on structure and enzymatic hydrolysis of treated steam explosion corn stover
}

Xu Yang ${ }^{1}$, Xiaojian Ma ${ }^{1,2^{*}}$, Hongliang $\mathrm{Li}^{1,2}$, Junyin Chen ${ }^{1,2}$ and Shuqi Fang ${ }^{1,2}$

\begin{abstract}
Background: Cellulase adsorption of lignocellulosic materials is the key link during enzymatic hydrolysis. Hot-washing process (above lignin glass transition temperature) was used to change the physical structure of lignin, decrease covalent connection between cellulose and lignin, reduce the concentration of inhibitor, and explore the feasibility of enzymatic hydrolysis. The general objective of the paper was conducted to determine whether the hot-washing process has the potential to change the mechanism of lignin on enzyme hydrolysis.

Results: Hot-washing was carried out at $151^{\circ} \mathrm{C}$ for $20 \mathrm{~min}$. The ratio of acid insoluble lignin to acid soluble lignin was increased, while the formation of spherical lignin droplets on the cell wall surface was decreased. Enzymatic digestibility of hot-washed filter cakes showed enhanced digestibility over the control samples. The concentration of fermentation inhibitor (acetic acid, formic acid, furfural and 5-hydroxymethylfurfural) obviously decreased after hotwashing process.

Conclusions: Hot-washing process significantly increased the adsorption ability of cellulase on the substrates and digestibility of biomass without removing much of the insoluble lignin content. Lignin distribution and/or physical property composition play a role.
\end{abstract}

Keywords: Corn stover, Hot-washing, Glass transition temperature, Lignin

\section{Background}

Lignocellulosic biomass is recognized as a high-potential feedstock for bio-ethanol production. It contains polymers of cellulose, hemicellulose, and lignin which bound together in a complex structure. Ethanol can be made from cellulose via four main consecutive steps: pretreatment, enzymatic hydrolysis, fermentation, and separation. One of the major limitations in the cellulosic ethanol production is the enzymatic hydrolysis step (Sun and Cheng 2002), where fermentable sugars are released from biomass using enzymes. The success of enzymatic hydrolysis depends on the accessibility of the cellulose component to hydrolytic enzymes (Stauner et al. 2013). In steam explosion pretreatment, hemicellulose is solubilized, whereas

\footnotetext{
*Correspondence: maxj@zzu.edu.cn

${ }^{1}$ School of Chemical Engineering and Energy, Zhengzhou University,

Zhengzhou 450001, Henan, People's Republic of China

Full list of author information is available at the end of the article
}

lignin and cellulose remain mostly insoluble. Residual lignin consolidating the polysaccharide matrix interferes with the action of enzyme, leading to decreased hydrolysis yields and rates (Zhang et al. 2015). Enzyme adsorption onto lignin surface is considered as a major inhibitory mechanism in the enzymatic hydrolysis of cellulose (Sun et al. 2014), which is largely determined by the glassy state structure of lignin (Piccolo et al. 2010). Many pretreatment strategies, such as hot-water pretreatment, focus on removing a significant fraction of lignin from biomass to enable better hydrolysis. However, lignin is partially depolymerized and solubilized during hot-water pretreatment, but complete delignification is not possible, because of the recondensation of soluble components originating from lignin (Alvira et al. 2010).

The "hot-wash" concept developed at National Renewable Energy Laboratory (NREL) uses hot water or hot dilute acid at temperatures above the lignin liquid/glass 
condensation temperature $\left(T_{\mathrm{g}}\right)$ to wash out the solubilized lignin. The previous works have characterized the glass transition behavior of lignin, where it transforms from a hard or glass-like state into a rubbery or viscous state upon heating (Ko et al. 2015). Hot-water pretreatments reaching temperatures above the range for lignin phase transition cause lignin to coalesce into larger molten bodies that migrate within and out of the cell wall, and can redeposit on the surface of plant cell walls upon cooling (Donohoe et al. 2008). During cooling after pretreatment, coalesced lignin could harden and either became trapped within the cell wall layers or settle out of the bulk liquid phase, potentially depositing back onto the biomass surface. Typically, the solid fraction is separated by filtration. The solid fraction allows solubilized lignin to condense and precipitate out on the cellulosic residue interfering with the enzymatic hydrolysis of cellulose to glucose (Selig et al. 2007). Flow-through hot-water pretreatment, where the solids residence time is longer than that of the liquid, has been shown to effectively dissolve more lignin compared with pretreatments, in which liquid and solids have the same residence time (Mosier et al. 2005). This method also generates solids that are more reactive on enzymatic hydrolysis, because of removing the solubilized lignin. However, continuous flow-through operation is thought to use an excessive amount of water and energy (Liu and Wyman 2005).

In this study, a pressure filter reactor was designed for solid-liquid separation during hot-water treatment. The separation temperature was above $T_{\mathrm{g}}$. Experiments were conducted to determine if the observed droplet formations do emerge from the biomass into the bulk liquid phase during pretreatment and whether or not they deposit back onto the biomass surface after pressure filtration. To understand the mechanism of lignin on enzyme hydrolysis, it is crucial to investigate the adsorption of cellulase on pretreated substrates. In addition, experimental sets were run in an attempt to determine whether the hot-washing process has the potential to affect the enzymatic saccharification of cellulose in the pretreated biomass.

\section{Methods}

\section{Materials}

Steam explosion corn stover (ECS) was supplied by Henan Tianguan Group Co., Ltd. The composition of raw and pretreated solids was analyzed following the NREL standard procedures (Sluiter et al. 2008). All the experiments were performed in duplicate, with the average value reported. The pretreated solids were air-dried and milled to pass 40 mesh screen for compositional analysis.

\section{Pretreatment of ECS}

ECS was treated with different solutions (water, $0.5 \%$ ethanol solution, $0.5 \%$ sulfuric acid solution) in a selfmade reactor (Fig. 1), with pressure filtration under $151{ }^{\circ} \mathrm{C}$ to give cakes. Approximately, $300 \mathrm{~g}$ of raw materials and $3000 \mathrm{~mL}$ of solution were loaded in the reactor. The pretreatment temperature was controlled at $151{ }^{\circ} \mathrm{C}$, the heating time to maximum temperature was $10 \mathrm{~min}$, and pretreatment time at the maximum temperature was set to $20 \mathrm{~min}$. After pretreatment, the solid and liquid fractions were separated by filtration using a filter plate at the $T_{\mathrm{g}}$ in the same reactor. The residual solid with water, ethanol, and sulfuric acid solution-treated ECS was named WECS, EECS, and SECS for the next assay and enzymolysis.

\section{Enzymatic hydrolysis of cellulosic substrates}

Cellic CTec 2 (the cellulase product for the production of cellulosic ethanol from Novozymes) was measured to have a cellulolytic activity of $117 \mathrm{FPU} / \mathrm{mL}$ as determined in our laboratory. Filter paper activity (FPA) measurement was carried out according to QB2583-2003.

Enzymatic hydrolysis was performed in $0.05 \mathrm{M}$ sodium acetate buffer solution ( $\mathrm{pH} 4.80)$ to control the same $\mathrm{pH}$. Cellulosic substrates by hot-washing process were added to a $500 \mathrm{~mL}$ round-bottomed flask with a stir and diluted with acetate buffer solution, to get a final solid concentration of $250 \mathrm{~g}$ per liter. The enzyme loading of cellulose was $10 \mathrm{IU} / \mathrm{g}$ cellulose. The reaction mixtures were put in a water bath at $50{ }^{\circ} \mathrm{C}$ for $48 \mathrm{~h}$.

\section{Cellulase adsorption kinetics studies}

The adsorption kinetics of cellulosic substrates was measured according to the methods by Tu et al. (2009). $100 \mathrm{mg}$ of substrates studied was suspended in $5 \mathrm{~mL}$ of $0.05 \mathrm{M}$ sodium acetate buffer solution ( $\mathrm{pH} 4.80)$ with $50 \mathrm{uL}$ cellulase. The adsorption experiments were carried out at $4{ }^{\circ} \mathrm{C}$ for $4 \mathrm{~h}$. The adsorbed capacity of substrate was calculated as follows:

$$
\mathrm{AC}_{\mathrm{s}}=\frac{\text { Mass of initial cellulase }- \text { Mass of cellulase in supernatant }}{\text { Mass of substrate }}
$$

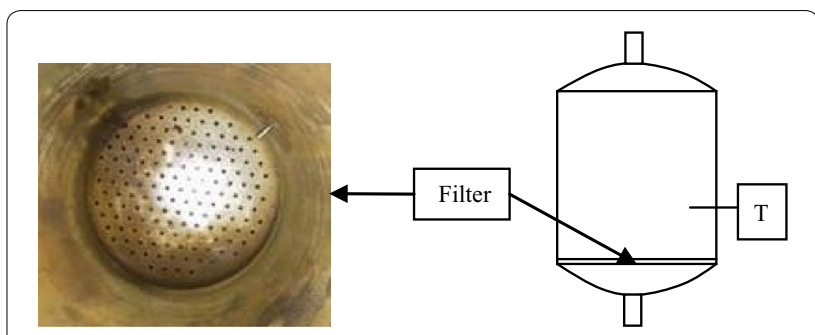

Fig. 1 Filter plate of the self-made reactor used in this study 
In which, $\mathrm{AC}_{\mathrm{S}}$ is the adsorption capacity of substrate.

\section{Cellulase adsorption isotherm studies}

The adsorption isotherms of cellulosic substrates were determined as follows. Different concentrations $(2-16 \mathrm{uL} / \mathrm{mL})$ of cellulase were incubated with $100 \mathrm{mg}$ of substrates in $5 \mathrm{~mL}$ of $0.05 \mathrm{M}$ sodium acetate buffer solution ( $\mathrm{pH} 4.80)$ at $4{ }^{\circ} \mathrm{C}$ for $2 \mathrm{~h}$, allowing to reach equilibrium. The cellulase activity in supernatant was determined for non-adsorbed cellulase. The adsorbed cellulase was calculated from the difference between the initial cellulase dosage and the non-adsorbed cellulase. The data were fitted by Langmuir adsorption isotherm with origin 8.0 software. The Langmuir expression is shown as follows (Kadam et al. 2004):

$$
E_{\mathrm{b}}=\frac{E_{\mathrm{max}} K_{\mathrm{ad}} E_{\mathrm{f}} S}{1+K_{\mathrm{ad}} E_{\mathrm{f}}}
$$

where $E_{\mathrm{b}}$ is the bound enzyme concentration $(\mathrm{U} / \mathrm{g}$ substrate), $E_{\mathrm{f}}$ is the free enzyme concentration $(\mathrm{U} / \mathrm{mL}), K_{\mathrm{ad}}$ is the dissociation constant for adsorption $(\mathrm{mL} / \mathrm{U}), S$ is the substrate concentration $(\mathrm{g} / \mathrm{mL})$, and $E_{\max }$ is the maximum adsorption capacity in amount of cellulase per amount of substrate (U/g substrate).

\section{Analysis}

Sugar, furfural, 5-hydroxymethylfurfural (HMF), acetic acid, and formic acid were analyzed by high-performance liquid chromatography (HPLC) using an HPX-87H $(300 \times 7.8 \mathrm{~mm})$ column operating at $60{ }^{\circ} \mathrm{C}$. The eluent, $5 \mathrm{mmol} / \mathrm{L} \mathrm{H}_{2} \mathrm{SO}_{4}$, was used at a flow rate of $0.5 \mathrm{~mL} / \mathrm{min}$ using a refractive index detector. All samples were centrifuged for $5 \mathrm{~min}$ to remove the water insoluble substances and the supernatant filtered through a $0.22 \mathrm{~mm}$ filter before analysis.

The $T_{\mathrm{g}}$ measurements was conducted using a simultaneous thermal analyzer (NETZSCH, STA409PC, USA). Scanning Electron Microscope (SEM) analysis was used to investigate physical changes in the native and pretreated materials. Fourier transform infrared spectroscopy (FTIR) was conducted using a Spectrum One FTIR system (Perkin Elemer) with a universal attenuated total reflection (ATR) accessory. Sample spectra were obtained using an average of 32 scans over the range between 400 and $4000 / \mathrm{cm}$ with a spectral resolution of $4 / \mathrm{cm}$.

\section{Results and discussion}

\section{Glass transition temperature $\left(T_{\mathbf{g}}\right)$}

Differential scanning calorimetry (DSC) defined the $T_{\mathrm{g}}$ as a change in the heat capacity when the polymer matrix goes from a glassy state to a rubbery state. This point was determined by a change in slope in DSC curves. As shown in Fig. 2, the observed $T_{\mathrm{g}}$ value for ECS occurred at a temperature of $151.1{ }^{\circ} \mathrm{C}$ ( $\left.T_{\text {midpoint }}\right)$. In general, the $T_{\mathrm{g}}$ of lignin ranges from 127 to $193{ }^{\circ} \mathrm{C}$, depending on their source, the functional groups, intermolecular bonding (cross-link) type, etc. (Hatakeyama and Hatakeyama 2004). These ranges agreed well with our data. Once pretreatment temperatures rise above the phase-transition temperature for lignin, lignin is fluidized and mobility is permitted within the confines of the cell wall matrix.

\section{Chemical composition}

To understand the fate of lignin during the hot-washing pretreatment, the lignin content of the pretreated material was analyzed following the NREL standard procedure (Table 1). 89.47-92.07\% of the lignin initially present was recovered in all the pretreated solids. The percentage of lignin decreased from $40.43 \mathrm{wt} \%$ for ECS to $37.40 \mathrm{wt} \%$ for EECS mainly due to the solubilization of lignin after pretreatment. While most of the initial lignin was retained in the pretreated solids, changes in the ratio of acid insoluble lignin (AIL) to acid soluble lignin (ASL) were observed. The AIL/ASL ratio increased from 7.60 to 10.60 in the case of SECS. The increase in the AIL/ASL ratio indicated that lignin changed its chemical composition or structure during pretreatment and was consistent with the literature (Samuel et al. 2010). ASL may represent the low-molecular-weight and hydrophilic derivatives of lignin (Yasuda et al. 2001). As also shown in the increase of the AIL/ASL ratio, lignin structure was assumed to be changed to more condensed and less reactive type during pretreatment. The extent of enzymatic hydrolysis can vary among fiber areas with comparable lignin contents due to the differences in lignin were distributed.

The main drawback of steam explosion pretreatment is the partially hemicelluloses degradation and the generation of some toxic compounds that can affect the following hydrolysis and fermentation steps (Oliva et al. 2003). The possible toxic compounds in ECS were organic acids, such as acetic acid and formic acid, furan derivatives, such as furfural, and HMF (Table 1). Several detoxification methods have been studied to reduce the inhibitory effect caused by these compounds on enzymes and yeasts. For example, after hot-water pretreatment, the solid fraction was washed with warm deionized water $\left(80^{\circ} \mathrm{C}\right)$ to remove inhibitors of cellulase enzymes (Zeng et al. 2012). However, owing to the additional cost in the overall process, detoxification should be avoided if possible. Due to filtering step under the high temperature, these compounds were separated from solid into the liquid phase. The concentration of these obviously decreased in solid samples after hot-washing process. The yield of formic acid in residual substrates decreased by about $90 \%$, and the concentration of acetic acid dropped from 0.29 to $0.035 \%$ in SECS. The content of furfural and HMF was well eliminated. 


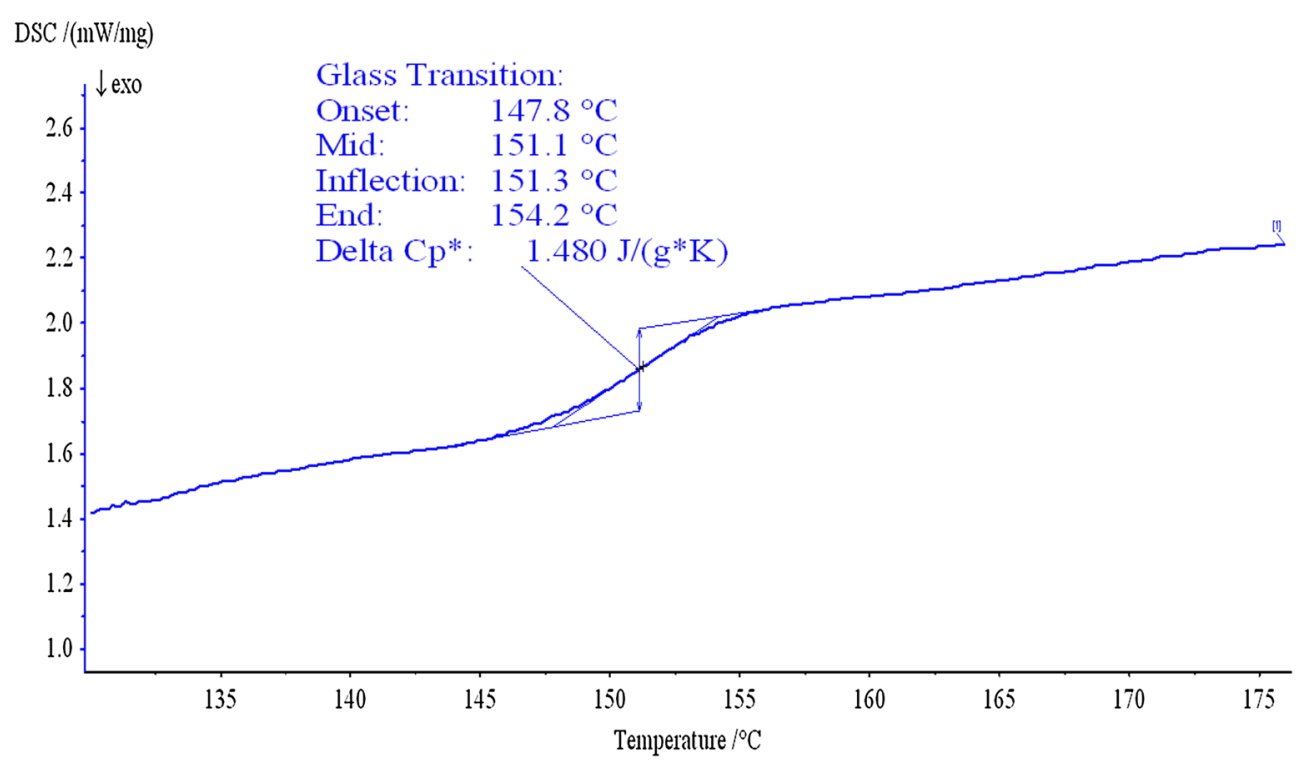

Fig. 2 DSC curves of steam explosion corn stover

Table 1 Chemical compositions of samples before and after hot-washing process (dry wt\%)

\begin{tabular}{lllll}
\hline & ECS & WECS & SECS & EECS \\
\hline Moisture & 48.55 & 56.89 & 57.64 & 54.9 \\
Glucan & 31.43 & 33.67 & 35.35 & 32.87 \\
Xylan & 0.67 & 0.68 & 0.95 & 0.71 \\
AlL $^{\text {a }}$ & 35.73 & 35.72 & 35.87 & 33.91 \\
ASL $^{\text {b }}$ & 4.7 & 3.65 & 3.38 & 3.49 \\
AlL/ASL ratio & 7.6 & 9.79 & 10.6 & 9.72 \\
Total lignin $^{c}$ & 40.43 & 39.37 & 39.25 & 37.4 \\
Lignin recovery $^{d}$ & - & 92.07 & 91.12 & 89.47 \\
Solid recovery & - & 94.55 & 93.86 & 96.72 \\
Formic acid & 0.14 & 0.017 & 0.016 & 0.018 \\
Acetic acid & 0.29 & 0.036 & 0.035 & 0.038 \\
Furfural & 0.033 & - & - & - \\
HMF & 0.026 & - & - & - \\
\hline
\end{tabular}

All the experiments were performed in duplicate, with the average value reported

a Acid insoluble Klason lignin

b Acid soluble Klason lignin

c Total lignin $(\%)=\{$ Acid insoluble lignin $(\mathrm{g}) /$ total biomass $(\mathrm{g}) \times 100\}+$ Acid soluble lignin (\%)

${ }^{d}$ Lignin recovery $(\%)=$ Lignin recovered in solid after pretreatment $(\mathrm{g}) /$ Initial amount of lignin $(g) \times 100$

\section{Morphology of the treated and untreated materials}

The change in the surface morphology during hot-washing steps was observed using SEM. Figure 3a showed the ECS, with very compact fiber structures due to the original structure of lignin. As seen from Fig. 3b-d, most small fragments attached on the surface of the substrate have been disrupted. The most noticeable change was the appearance of spherical droplets on the surface in hotwashing materials, while those were not found in ECS. It has been suggested that the formation or redistribution of lignin droplets on cell walls usually occurred during hydrothermal pretreatment. The morphological change of lignin was irreversible after cooling, similar structural changes have been reported earlier (van Dam et al. 2004). The deposition of droplets produced was shown to have a negative effect on the enzymatic saccharification of substrate. Compared with the traditional hydrothermal pretreatment, the overall surface droplet density generally decreased with hot-washing process and pressure filtration to give cakes above $T_{\mathrm{g}}$. This consequence of lignin deposition also agrees well with published findings regarding high temperature, flow-through pretreatment, which increases in the enzymatic digestibility of the pretreated material when portions of lignin were removed by washing during the pretreatment process (Archambault-Leger et al. 2012).

\section{Fourier transform infrared spectroscopy (FTIR) analysis}

FTIR spectroscopy was used to demonstrate the physical structure and functional groups of the lignocellulosic materials. The IR spectra of the untreated and treated materials were shown in Fig. 4 . The characteristic peaks of cellulose $(1167 / \mathrm{cm}, \mathrm{C}-\mathrm{O}-\mathrm{C}$ vibration; $1375 / \mathrm{cm}, \mathrm{C}-\mathrm{H}$ deformation) existed indicated that after hot-washing treatment, the cellulose was not hydrolyzed. The hydrolysis of cellulose requires higher temperature. The peak in the $1233 / \mathrm{cm}$ was associated to the $\mathrm{C}-\mathrm{O}$ stretching of the 

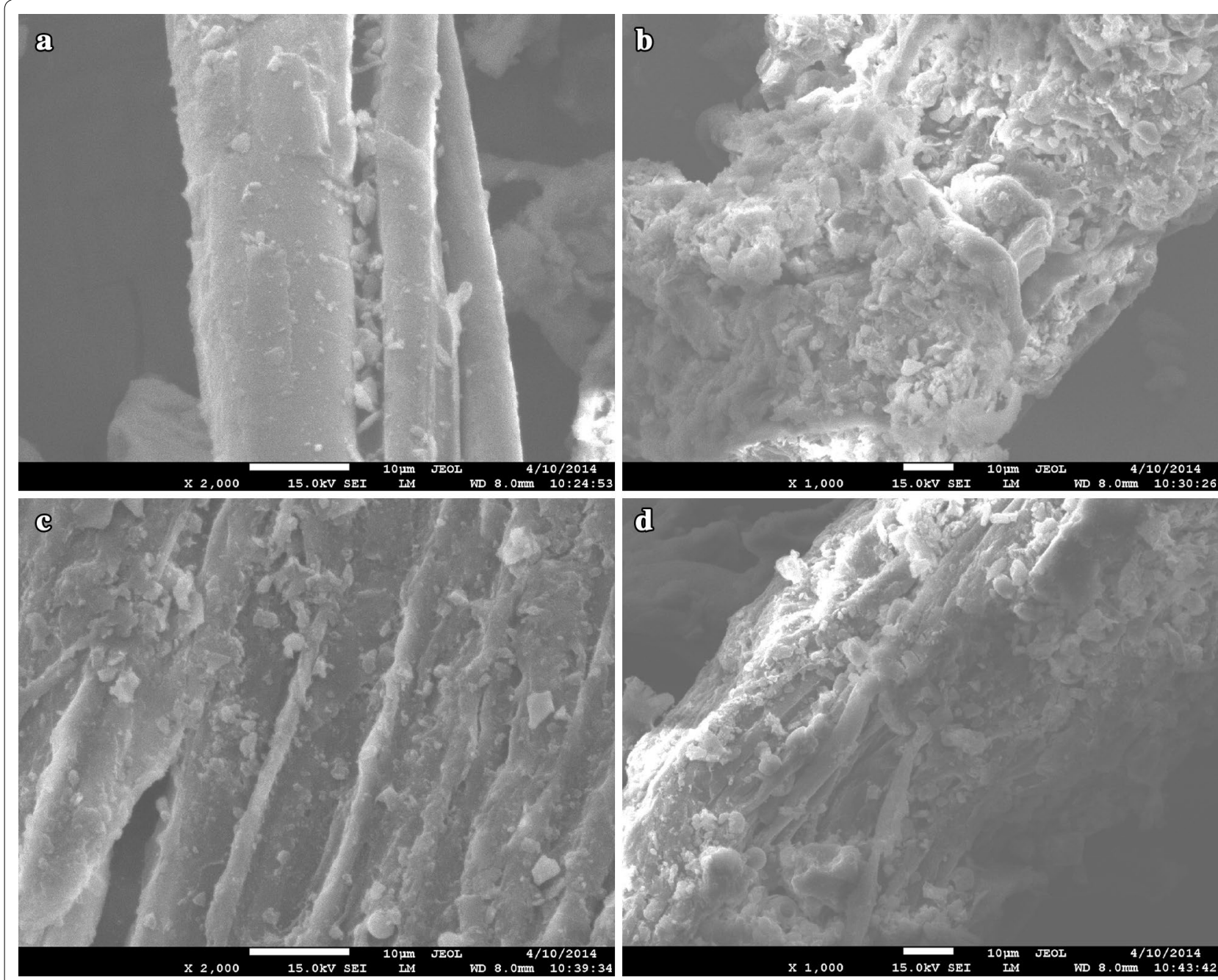

Fig. 3 SEM micrographs of the materials before and after chemical treatment for: a ECS, b WECS, c SECS, and $\mathbf{d}$ EECS

aryl group in lignin (Trodec et al. 2008). The decrease of this peak in all the hot-washing samples was believed to be due to the removal of free lignin after the chemical treatments. The typical bands at 1425 and $1501 / \mathrm{cm}$ represent aromatic ring vibrations of lignin (Sun et al. 2015). The intensity of methoxyl group at $1425 / \mathrm{cm}$ showed a decreasing tendency in all the hot-washing samples. The hydrolysis of methoxyl group can be attributed to the degradation of aromatic rings and breakage of ether linkages. During hydrothermal pretreatment, the depolymerized lignin by the cleavage of ether linkages undergoes condensation reaction with the formation of $\mathrm{C}-\mathrm{C}$ bonding which is more rigid and less reactive ( $\mathrm{Li}$ et al. 2007). By hot-washing process, the aromatic skeletal vibration at $1501 / \mathrm{cm}$ decreased. It illustrated that hot-washing process was able to destroy the aromatic skeletal carbon of lignin. Compared with the curve of ECS, the $\mathrm{OH}$ peak $(3447 / \mathrm{cm})$ of the treated samples can be observed.
Combination with water during the pretreatment and the absence of some impurities may account for this.

\section{Adsorption kinetics of biomass substrates}

The first step in enzymatic hydrolysis of substrates is the adsorption of cellulase on the substrate cellulose surface. Furthermore, lignin is also reported to adsorpt cellulase enzymes in many studies (Kumar and Wyman 2009). Investigation of adsorption kinetics on lignocelluloses contributes to the understanding the enzymatic hydrolysis of lignocelluloses.

Cellulase adsorption kinetics on four substrates samples were studied at $4{ }^{\circ} \mathrm{C}$. At this temperature, enzymatic hydrolysis of cellulosic substrates was negligible. The results of adsorption kinetics were shown in Fig. 5. The results indicate that the adsorption kinetics on ECS was distinct from the other substrates. First, the equilibrium time for cellulase enzymes on ECS was over 


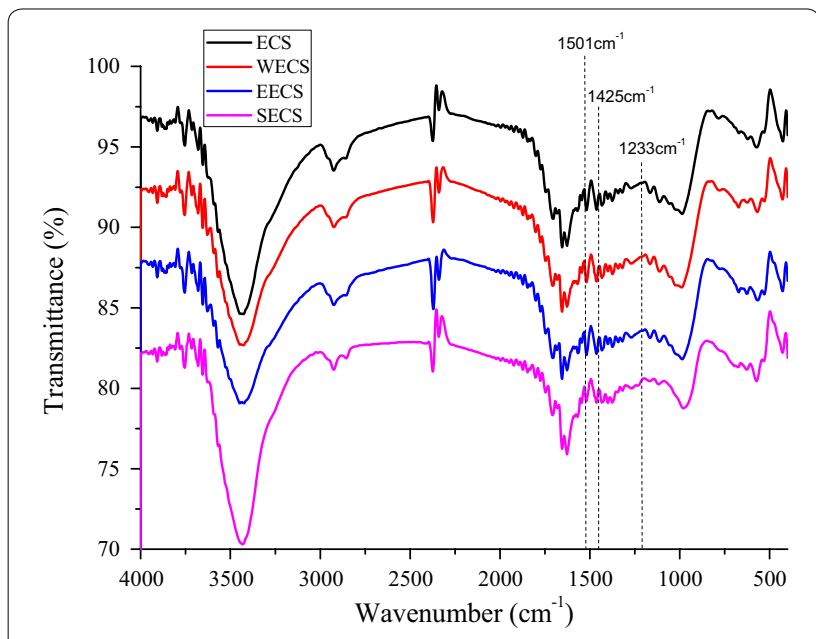

Fig. 4 Infrared spectra of the ECS, WECS, SECS, and EECS

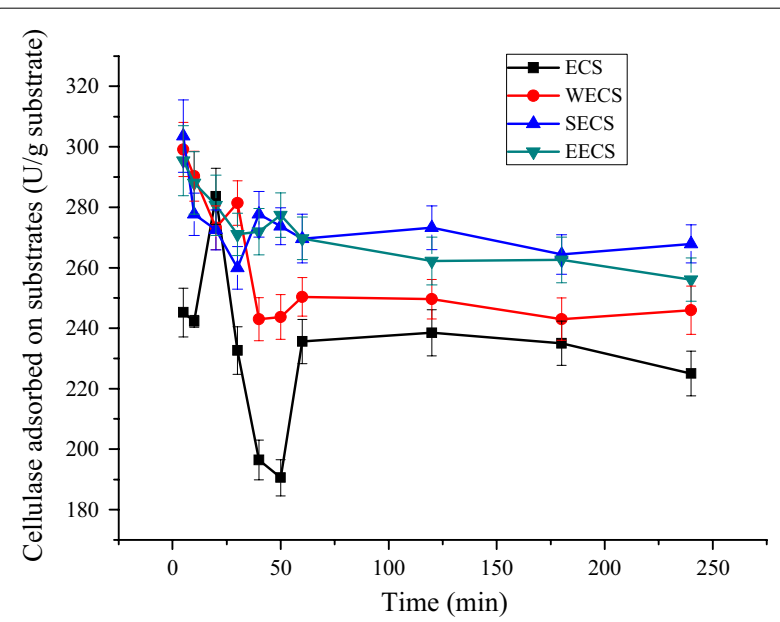

Fig. 5 Cellulase adsorption kinetics of cellulosic substrates at $4{ }^{\circ} \mathrm{C}$ $100 \mathrm{mg}$ substrates were incubated in $5 \mathrm{~mL}$ of $0.05 \mathrm{M}$ sodium acetate buffer ( $\mathrm{pH}$ 4.8) for $4 \mathrm{~h}$

50 min, longer than that on EECS, WECS, and SECS. Moreover, the pattern of adsorption kinetics curves of ECS and other substrates was considerably different. Amount of cellulase absorbed on ECS reached an equilibrium value $(\sim 235 \mathrm{U} / \mathrm{g})$ in $20 \mathrm{~min}$. EECS, WECS, and SECS substrates were similar and had no obvious peaks for adsorption amount. Amount of enzymes absorbed on other cellulosic substrates increased to a maximum value (240-270 U/g) in $5 \mathrm{~min}$ and reached equilibrium plateau. The result suggests that enzyme adsorption on ECS was not stable and some enzyme could be released again after adsorption. Enzyme adsorbed on cellulose was a more rapid process than that of ECS according to the adsorption kinetics. Therefore, at the beginning of hydrolysis, the hydrolysis rate was high. With the increase of enzyme adsorbed on ECS, the decrease of hydrolysis rate was probably due to more unproductive binding of enzyme.

\section{Adsorption isotherm of biomass substrates}

To determine the adsorption isotherm of different substrates, enzymes preparations with various concentrations were carried out. The enzyme activity in the supernatant was determined. The data shown in Fig. 6 indicated that the adsorption isotherms on various lignocellulosic substrates were well fitted to the Langmuir adsorption model. The maximum adsorption capacity and Langmuir constant were obtained from adsorption isotherm and listed in Table 2. The data again revealed that there was obvious difference between cellulosic substrates. The maximum adsorption capacity of EECS was $1168.88 \mathrm{U} / \mathrm{g}$ of solid, which was about three times that of ECS $\left(E_{\max }=427.50 \pm 19.53 \mathrm{U} / \mathrm{g}\right)$. The accessibility of lignocellulosic substrates was usually indicated by the maximum adsorption capacity, so EECS had more accessibility than ECS. Langmuir constant has often been used to evaluate the affinity of enzyme on different substrates (Min et al. 2015), although the actual adsorption behavior of enzyme on substrates may be not a reversible monolayer adsorption. The data in Table 2 showed that ECS had the lowest affinity $\left(K_{\mathrm{ad}}=0.013 \pm 0.008 \mathrm{~mL} / \mathrm{U}\right)$ to enzyme. In contrast to this, SECS which had the lowest adsorption capacity had the highest affinity $\left(K_{\mathrm{ad}}=0.028 \pm 0.018 \mathrm{~mL} / \mathrm{U}\right)$. The results suggested that WECS and SECS had more affinity than ECS.

\section{Enzyme hydrolysis}

The effect on enzymatic hydrolysis of hot-washing materials was investigated at $50{ }^{\circ} \mathrm{C}$. The results shown in Fig. 7 demonstrated that hot-washing process significantly enhanced the enzyme hydrolysis of cellulosic substrates. As an average, $71.90 \%$ of cellulose conversion was attained of ECS. A significant increase was observed in the case of WECS (81.47\%), SECS (80.53\%), and EECS $(85.18 \%)$. The cellulose digestibility increased as a function of hot-washing pretreatment.

\section{Conclusions}

Hot-washing process had a significant effect on ESC's physic-mechanical properties. It suggests that upon melting under $T_{\mathrm{g}}$, lignin in biomass becomes fluid, coalesce, and has potential to move throughout the cell wall matrix. Hot-washing process significantly increased the adsorption ability of enzymes onto the substrates and digestibility of biomass without removing much of the insoluble lignin content. The amount of lignin alone was not sufficient to explain the different enzymatic hydrolysis characteristics of the fractions. Lignin distribution and/or physical property composition play a role. The concentration of fermentation inhibitor (acetic acid, 

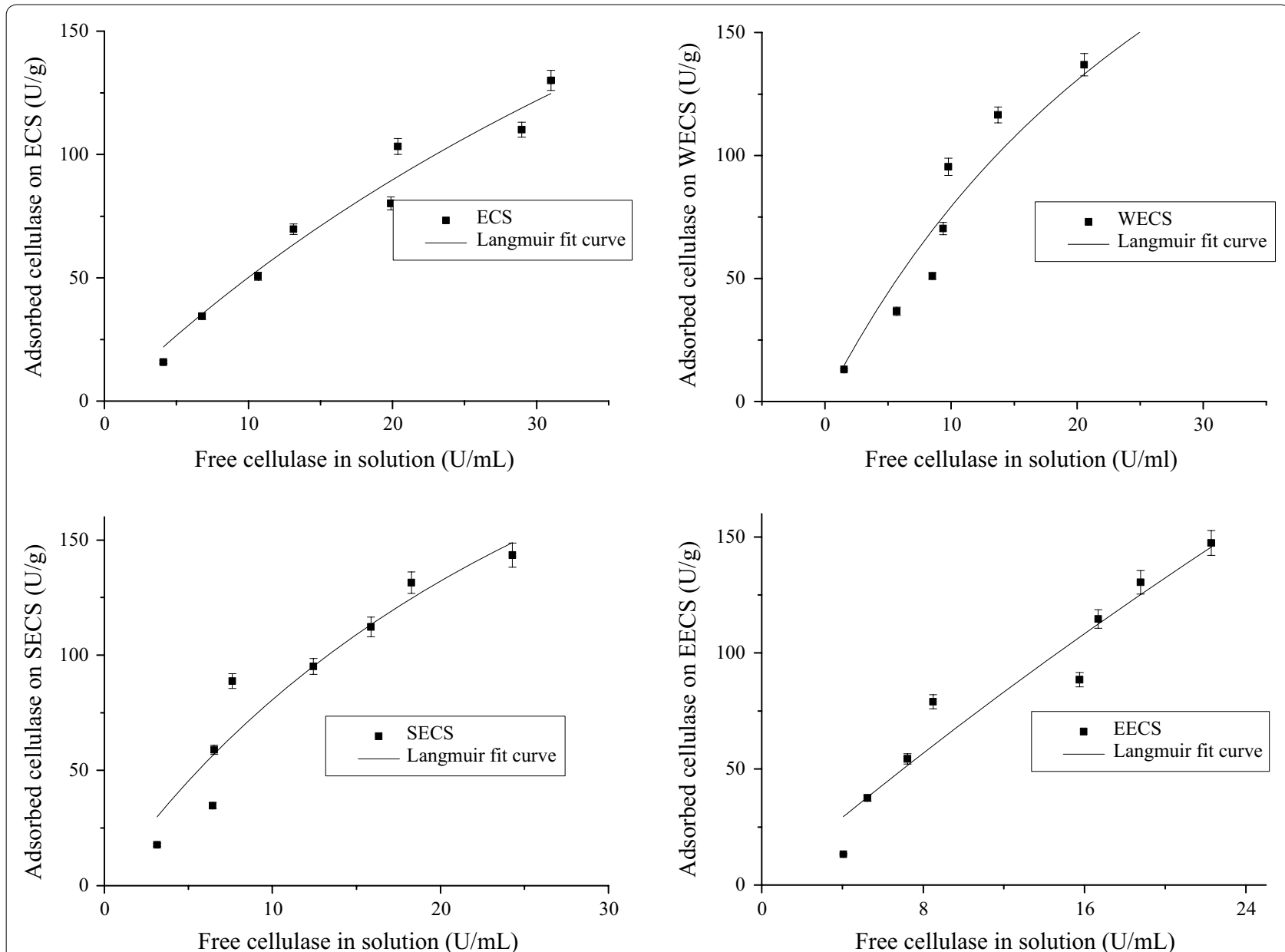

Fig. 6 Adsorption isotherm of cellulosic substrates was at $4^{\circ} .100 \mathrm{mg}$ substrates were incubated in $5 \mathrm{~mL}$ of sodium acetate buffer ( $\left.\mathrm{pH} 4.8\right)$ with various cellulase concentrations ( $10-80 \mathrm{ul}$ ) for $2 \mathrm{~h}$ to reach equilibrium. The curves were fitted by Langmuir expression

Table 2 Adsorption isotherm parameters of cellulase fitted by Langmuir adsorption model on different substrates at $4^{\circ}$

\begin{tabular}{lccc}
\hline Substrate & $\boldsymbol{E}_{\max }(\mathbf{U} / \mathbf{g})$ & $\boldsymbol{K}_{\text {ad }}(\mathbf{m L} / \mathbf{U})$ & $\boldsymbol{A d j} \boldsymbol{R}^{\mathbf{2}}$ \\
\hline ECS & $427.5 \pm 19.53$ & $0.013 \pm 0.008$ & 0.955 \\
WECS & $373.63 \pm 12.92$ & $0.027 \pm 0.014$ & 0.923 \\
SECS & $364.04 \pm 16$ & $0.028 \pm 0.018$ & 0.895 \\
EECS & $1168.88 \pm 206.75$ & $0.0064 \pm 0.013$ & 0.923
\end{tabular}

Values are presented as means \pm standard deviations $(n=3)$

formic acid, furfural, and HMF) obviously decreased after hot-washing process. Future work is focused on the industrial equipment, which can be carried out to pressure filtration under high temperature.

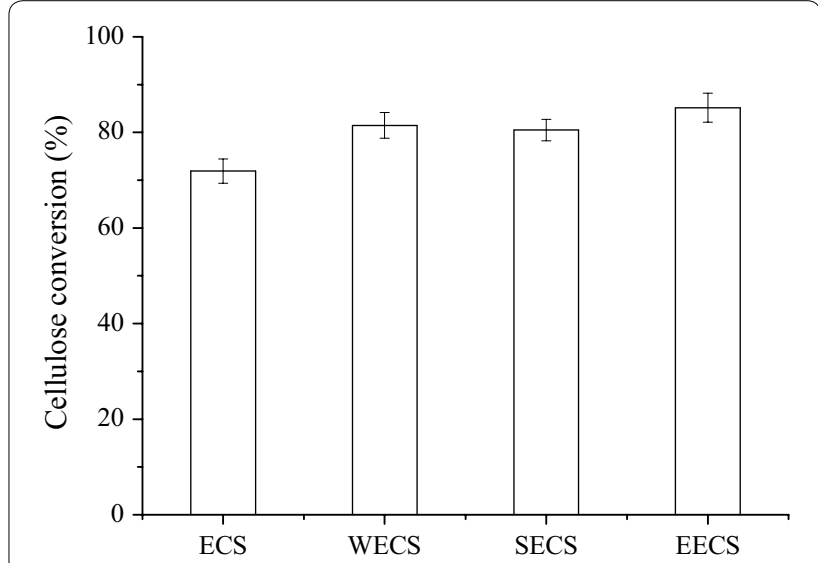

Fig. 7 Effect on enzymatic hydrolysis of hot-washing materials 


\section{Authors' contributions}

XY wrote this manuscript. HLL, JYC, and SQF contributed general advice. XJM edited the manuscript. All authors read and approved the final manuscript.

\section{Author details}

${ }^{1}$ School of Chemical Engineering and Energy, Zhengzhou University, Zhengzhou 450001, Henan, People's Republic of China. ${ }^{2}$ Engineering Laboratory of Henan Province for Biorefinery Technology and Equipment, Zhengzhou 450001, Henan, People's Republic of China.

\section{Competing interests}

The authors declare that they have no competing interests.

Received: 24 April 2016 Accepted: 28 July 2016

Published online: 18 August 2016

\section{References}

Alvira P,Tomás-Pejó E, Ballesteros M, Negro MJ (2010) Pretreatment technologies for an efficient bioethanol production process based on enzymatic hydrolysis: a review. Bioresour Technol 101(13):4851-4861

Archambault-Leger V, Shao XJ, Lynd LR (2012) Integrated analysis of hydrothermal flow through pretreatment. Biotechnol Biofuels 5:49

Donohoe BS, Decker SR, Tucker MP, Himmel ME, Vinzant TB (2008) Visualizing lignin coalescence and migration through maize cell walls following thermochemical pretreatment. Biotechnol Bioeng 101(5):913-925

Hatakeyama T, Hatakeyama H (2004) Thermal properties of green polymers and biocomposites. Kluwer Academic Publishers, Dortrecht, pp 171-215

Kadam KL, Rydholm EC, McMillan JD (2004) Development and validation of a kinetic model for enzymatic saccharification of lignocellulosic biomass. Biotechnol Progr. 20:698-705

Ko JK, Kim Y, Ximenes E, Ladisch MR (2015) Effect of liquid hot water pretreatment severity on properties of hardwood lignin and enzymatic hydrolysis of cellulose. Biotechnol Bioeng 112:252-262

Kumar R, Wyman CE (2009) Effects of cellulase and xylanase enzymes on the deconstruction of solids from pretreatment of poplar by leading technologies. Biotechnol Prog 25:302-314

Li J, Henriksson G, Gellerstedt G (2007) Lignin depolymerization/repolymerization and its critical role for delignification of aspen wood by steam explosion. Bioresour Technol 98:3061-3068

Liu C, Wyman CE (2005) Partial flow of compressed-hot water through corn stover to enhance hemicellulose sugar recovery and enzymatic digestibility of cellulose. Bioresour Technol 96(18):1978-1985

Min BC, Bhayani BV, Jampana VS, Ramarao BV (2015) Enhancement of the enzymatic hydrolysis of fines from recycled paper mill waste rejects. Bioresour Bioprocess 2(1):1-10

Mosier N, Wyman C, Dale B, Elander R, Lee YY, Holtzapple M (2005) Features of promising technologies for pretreatment of lignocellulosic biomass. Bioresour Technol 96:673-686
Oliva JM, Sáez F, Ballesteros I, González A, Negro MJ, Manzanares P, Ballesteros M (2003) Effect of lignocellulosic degradation compounds from steam explosion pretreatment on ethanol fermentation by thermotolerant yeast Kluyveromyces marxianus. Appl Microbiol Biotechnol 105:141-153

Piccolo C, Wiman M, Bezzo F, Lidén G (2010) Enzyme adsorption on $\mathrm{SO}_{2}{ }^{-}$ catalyzed steam-pretreated wheat and spruce material. Enzyme Microb Technol 46:159-169

Samuel R, Pu Y, Raman B, Ragauskas AJ (2010) Structural characterization and comparison of switchgrassbass-milled lignin before and after dilute acid pretreatment. Appl Biochem Biotechnol 162:62-74

Selig MJ, Viamajala S, Decker SR, Tucker MP, Himmel ME, Vinzant TB (2007) Deposition of lignin droplets produced during dilute acid pretreatment of maize stems retards enzymatic hydrolysis of cellulose. Biotechnol Prog 23(6):1333-1339

Sluiter A, Hames B, Ruiz R, Scarlata C, Sluiter J, Templeton D (2008) Determination of structural carbohydrates and lignin in biomass, Laboratory Analytical Procedure, NREL Report No. TP-510-42618

Stauner T, Silva IB, El Seoud OA, Frollini E, Petri DFS (2013) Cellulose loading and water sorption value as important parameters for the enzymatic hydrolysis of cellulose. Cellulose 20:1109-1119

Sun Y, Cheng J (2002) Hydrolysis of lignocellulosic materials for ethanol production: a review. Bioresour Technol 83:1-11

Sun SN, Cao XF, Sun SL, Xu F, Song XL, Sun RC, Jones GL (2014) Improving the enzymatic hydrolysis of thermo-mechanical fiber from Eucalyptus urophylla by a combination of hydrothermal pretreatment and alkali fractionation. Biotechnol Biofuels 7:116

Sun Shao-Ni, Li Han-Yin, Cao Xue-Fei, Feng Xu, Sun Run-Cang (2015) Structural variation of eucalyptus lignin in a combination of hydrothermal and alkali treatments. Bioresour Technol 176:296-299

Trodec ML, Sedan D, Peyratout C, Bonner JP, Smith A, Guinebretiere R, Gloaguen $V$, Krausz P (2008) Influence of various chemical treatments on the composition and structure of hemp fibers. Compos Part A 39:514-522

Tu M, Pan X, Saddler JN (2009) Adsorption of cellulase on cellulolytic enzyme lignin from lodgepole pine. J Agric Food Chem 57:7771-7778

van Dam JEG, van Den Oever MJA, Wouter T, Keijsers ERP, Peralta AG (2004) Process for production of high density/high performance binderless boards from whole coconut husk.Pare 1: lignin as intrinsic thermosetting binder resin. Ind Crop Prod 19:207-216

Yasuda S, Fukushima K, Kakehi A (2001) Formation and chemical structures of acid-soluble lignin 1: sulfuric acid treatment time and acid-soluble lignin content of hardwood. J Wood Sci 47:69-72

Zeng M, Ximenes E, Ladisch MR, Mosier NS, Vermerris W, Huang CP, Sherman DM (2012) Tissue-specific biomass recalcitrance in corn stover pretreated with liquid hot-water:enzymatic hydrolysis (part 1). Biotechnol Bioeng 109:390-397

Zhang ZC, Xia LL, Wang F, Lv P, Zhu MXQ, Li JH, Chen KP (2015) Lignin degradation in corn stalk by combined method of $\mathrm{H}_{2} \mathrm{O} 2$ hydrolysis and Aspergillus oryzae CGMCC5992 liquid-state fermentation. Biotechnol Biofuels 8:183

\section{Submit your manuscript to a SpringerOpen ${ }^{\circledR}$ journal and benefit from:}

- Convenient online submission

- Rigorous peer review

- Immediate publication on acceptance

- Open access: articles freely available online

- High visibility within the field

- Retaining the copyright to your article

Submit your next manuscript at springeropen.com 